\title{
The Groundwater Vulnerability Researches of Horqin District in Tongliao City Based on the AHP Method
}

\author{
Li Xuguang ${ }^{1}$, Dai Yajian ${ }^{1, *}$, He Haiyang ${ }^{1}$ \\ ${ }^{1}$ Shenyang Center of Geological Survey, China Geological Survey, Shenyang,Liao Ning, China
}

\begin{abstract}
On the basis of DRASTIC model index system, combined with the actual situation in Horqin district in Tongliao City, this paper removed the influence of the topography, added land use effects, modified the new model DRASLIC, used analytic Hierarchy Process (AHP), and calculated the new evaluation results. Groundwater management and protection decisions in Tongliao Horqin area provide a reliable basis for the application to design the groundwater monitoring network, site selection of waste landfill, evaluation and control of groundwater pollution, and provide a basis for other work. such as groundwater contamination and protection.
\end{abstract}

\section{INTRODUCTION}

As China releases relevant policies about revitalization of the old northeast industrial base, the economy in the Northeast Region is booming in recent years, with an increase of population and an expansion of cities. However, the contradiction between supply and demand of water resources is becoming more and more prominent. In particular, the decrease of precipitation in recent years has caused a serious shortage of surface water in the region, and groundwater resources seem particularly important in the Northeast Region. However, the groundwater level in the region gradually decreases with the exploitation of groundwater in quantity. Centralized water supply in urban areas results in the heavy groundwater exploitation. In addition, groundwater is polluted to varied degrees under the influence of industrial waste water, domestic sewage and agricultural irrigation. Tongliao City is one of the most important prefecture-level cities on the West Liaohe Plain in the Northeast Region. Particularly, Horqin Region, Tongliao has concentrated urbanization, dense population, developed industry and high pollution. Groundwater is the main water supply for residents in the region. The pollution of groundwater environment will seriously affect the production and life of local residents. The phreatic aquifer in the region is very thick, and shallow groundwater is distributed continuously, which is closely related to the circle of human activities on the surface and is most vulnerable to pollution. It is also closely associated with the hydraulic power of deep groundwater and easily contaminates other aquifers through interlayer hydraulic connection after pollution. Hence, it is crucial to evaluate the antifouling performance of shallow water.

\section{OVERVIEW OF STUDY AREA}

\subsection{Natural conditions}

The study area is located in the central part of the West Liaohe Alluvial Plain and the hinterland of Horqin Grassland. With regard to the terrain, Horqin Region is high in the south and north and low in the central part, with a height above sea level of 144.9-260 m. The south part has high topographic relief and is dominated by sand hump land. East-west closed strip-shape depressions are common among humps. In the north, the topography is undulating and humps and recesses are connected; there are local closed depressions. The central part is a valley plain with wide and flat terrain inclined towards the northeast from the southwest. The study area is located in the central part of the West Liaohe Plain and belongs to Horqin Region, Tongliao, Inner Mongolia. It is the political, cultural, economic and transportation center of the east part of Inner Mongolia, with excellent traffic locations and a three-dimensional transportation network consisting of civil aviation, highways and railways. It is also a main transportation hub in the Northeast Region.

\subsection{Hydrogeology}

The study area is located in the hinterland of the West Liaohe Plain, in which there are extremely thick Quaternary loose sediments and simple exposed strata that are all Upper Pleistocene and Holocene strata of the Quaternary system. The aquifer structure and lithology in

Author: Li Xuguang, male, born in 1982, Master Degree Candidate, Senior Engineer, mainly engaged in groundwater pollution, endemic disease and urban geology. Email: john2011@163.com.

* Corresponding author:Dai Yajian, male, born in 1980, Master Degree Candidate, Senior Engineer, mainly engaged in groundwater pollution and pedogeochemistry. Email: 337056992@qq.com. 
the area have zoning rules from the west and south to the northeast consistent with the stratigraphic structure and lithology. In terms of the lithology, the aquifer in the west and south regions is featured with thick-layer fine sand, medium sand, coarse sand and sand pebbles and gravels with coarser grains and a single structure. The aquifer in the northeast is featured by silt and fine sand, increased and thickened interlayers of cohesive soil, finer grains and increased silt composition. The thickness of the aquifer group gradually decreases from west to east. From the west to the northeast and the southeast, the aquifer thickness shows a zoning rule of $130-<60 \mathrm{~m}$ and 130$<120 \mathrm{~m}$ respectively. The buried depth of groundwater varies greatly and is $3-10 \mathrm{~m}$ in most areas. That in the sand hump land in the south of Honghe River is extremely variable due to high topographic relief and frequent changes. It is generally $5-10 \mathrm{~m}$ and is greater than $10 \mathrm{~m}$ in some areas in the southeast. The buried depth of groundwater in the valley plain is generally small, 1-3 m in most areas.

\section{RESEARCH METHOD AND CONTENT}

\subsection{Evaluation method}

The antifouling performance of groundwater is a process with dynamic changes. Different evaluation periods will lead to different results. At present, it is common to evaluate the antifouling performance of groundwater with the DRASTIC method jointly developed by the US Environmental Protection Agency (USEPA) and the US National Wells Association (NWWA) in 1987, which combines the experience of more than 40 credible experts in hydrogeology and is an empirical model for macroscopic evaluation of the antifouling performance of regional groundwater on a large scale. The DRASTIC model was first used in 40 counties in the United States and in areas with different hydrogeological conditions. It was then used to evaluate the antifouling performance of groundwater in a wider range in different countries and regions and was improved to be applicable to the evaluation of the antifouling performance of groundwater under various hydrogeological conditions.

The traditional DRASTIC model adopts seven factor systems related to groundwater vulnerability evaluation:

(1) Depth to groundwater table D;

(2) Net recharge R;

(3) Aquifer media A;

(4) Soil media S;

(5) Terrain T;

(6) Impact of unsaturated zone I;

(7) Hydraulic conductivity C;

The expression (Formula 1) in the traditional DRASTIC model is:

$\mathrm{DI}=D_{W} D_{r}+R_{W} R_{r}+A_{W} A_{r}+S_{W} S_{r}+T_{W} T_{r}+I_{W} I_{r}+C_{W} C_{r}$

......Formula 1

Where,

DI is the antifouling performance index in DRASTIC (groundwater vulnerability index);

$\mathrm{Dr}, \mathrm{Rr}, \ldots, \mathrm{Cr}$ are the scores of evaluation index factors, respectively;

$\mathrm{Dw}, \mathrm{Rw}, \ldots, \mathrm{Cw}$ are the weighted values of evaluation index factors, respectively;

The higher the DI result (groundwater vulnerability index) calculated with the model, the worse the antifouling performance of groundwater (higher groundwater vulnerability) and the higher the risk of groundwater pollution; vice versa.

\subsection{Selection of evaluation factors}

All the seven parameters involved in the evaluation system are generally used as evaluation indexes in the evaluation of antifouling performance. However, it is necessary to make appropriate adjustments objectively and increase or decrease evaluation indexes based on the actual situation and the actual data collected and collated for different regions and evaluation work.

1. Soil lithology: the part of the evaluation system that is connected with the surface and most affected by human activities. Different soil lithology is different in structure, composition, thickness and natural humidity which determine its self-purification capacity, that is, the ability to adsorb and degrade pollution components. The stronger the self-purification capacity of soil, the higher the antifouling performance of groundwater. Therefore, soil lithology is one of the main indexes determining the antifouling performance.

2. Vadose zone: the medium between the soil medium and the medium of the water-bearing rock formation and the main path for pollution components to enter the groundwater. The lithology in the vadose zone determines the dilution function, biodegradation function, neutralization function and chemical reaction strength of pollution components before they enter the groundwater. Hence, it determines the antifouling performance of groundwater to a large extent.

3. Aquifer: a complex system, the vulnerability of which varies spatially. During analysis of the lithology of an aquifer, its hydraulic conductivity coefficient should also be regarded as an important index, which restricts the migration of groundwater and controls the migration of pollution components in groundwater. In addition, the buried depth of groundwater also has great impacts on the evaluation results in the process of phreatic aquifer vulnerability evaluation.

4. Terrain: the change of surface slope or land use type in the study area.

5. Recharge: the amount of water per unit area seeping into the aquifer from groundwater recharge sources. Net recharge is also an index reflecting aquifer vulnerability.

Based on the collected actual data of Horqin Region, Tongliao, we chose 7 index factors to build a model for evaluating the antifouling performance (vulnerability) of groundwater in the region, including the depth to groundwater table (D), net recharge (R), aquifer media (A), soil media (S), land use (L), impact of the vadose zone (I) and hydraulic conductivity $(\mathrm{C})$.

Six factors reflecting the groundwater properties in the working area were selected for the groundwater vulnerability evaluation based on DRASTIC model - the 
traditional groundwater vulnerability assessment method. The factors land use reflecting the pollution load was added. Therefore, 7 factors in total were used for the evaluation of regional groundwater pollution risks. The modified model is DRASLIC, the abbreviation of the following.

(1) D (Depth to groundwater table):

(2) R (Net recharge):

(3) A (Aquifer media):

(4) S (Soil media):

(5) L (Land use):

(6) I (Impact of the vadose zone):

(7) $\mathrm{C}$ (Hydraulic conductivity):

Depth to groundwater table (D). It was directly obtained from groundwater statistical and survey data in the evaluation, $\mathrm{m}$.

Net recharge $(R)$. The main recharge of groundwater in the area is the infiltration of atmospheric precipitation, accounting for more than $80 \%$ of the total recharge. For the convenience of calculation, the net recharge was approximately replaced by the infiltration of atmospheric precipitation, $\mathrm{mm}$.

Aquifer media (A) and impact of the vadose zone (I). They were modified based on loose strata since they are classified by rock (bed rock) in the Technical Requirements for Groundwater Vulnerability Assessment (GWI-D3) and the strata in the study area are all Quaternary loose strata. The level and characteristic value of the modified aquifer media (A) and impact of the vadose zone (I) were used.

Soil media (S). A value was assigned to it according to the level and characteristic value corresponding to the surface lithology and the surface lithology distribution diagram.

Land use (L). Its category and score were determined according to the land use status subject to remote sensing interpretation, the classification and scoring of land use in USGS and SI methods and the actual situation of the working area .

Hydraulic conductivity (C). A value was directly assigned according to the hydraulic conductivity distribution diagram of the aquifer, $\mathrm{m} / \mathrm{d}$.

\subsection{Weight calculation}

The weight of each evaluation factor can usually be obtained from the table when the DRASTIC evaluation method is used.

However, the table is based on the information about hydrogeological characteristics of the United States, so the weight of each factor is not always appropriate for Horqin Region, Tongliao. In order to make the evaluation result more accurate, the idea of AHP and the method of factor weight calculation in it are used to obtain the weight of each factor of DRASLIC.

Weight calculation method

Analytic Hierarchy Process (AHP) is a systematic and hierarchical analysis method combining qualitative and quantitative indexes, which was put forward by T.L. Satyr, a famous operations research expert and professor in the Department of Mathematics, the University of
Pittsburgh, in the middle 1970s. It is used to calculate the combined weight of components of each hierarchy to the target layer in four steps under the premise of clear and correct understanding of problems: setup of a structural model, construction of a judgment matrix, single hierarchical sorting and total hierarchical sorting, thus obtaining the comprehensive evaluation value of different operational schemes. AHP is a simple, flexible and practical multi-criteria decision-making method, which has been applied to decision-making issues in all walks of life since it was proposed.

Index weight calculation by APH

(1) Construct a hierarchical structure model according to the evaluation index system;

(2) Compare the factors $(\mathrm{a} 1, \mathrm{a} 2 、 \cdots \cdot \mathrm{an})$ in each target layer $(\mathrm{C})$ pairwise and construct a fuzzy consistent matrix (Formula 2) $\mathrm{R}$ according to the membership:

$$
\begin{array}{ccccc}
C & a_{1} & a_{2} & \cdots & a_{n} \\
a_{1} & r_{11} & r_{12} & \cdots & r_{1 n} \\
a_{2} & r_{21} & r_{22} & \cdots & r_{2 n} \\
\cdots & \cdots & \cdots & \cdots & \cdots \\
a_{n} & R_{n 1} & R_{n 2} & \cdots & r_{n n}
\end{array}
$$$$
\text { Formula } 2
$$

Where,

$\mathrm{r}_{\mathrm{ij}}$ means that elements ai and aj have a fuzzy relation "... much more important than..." when they are compared with target $\mathrm{C}$.

To quantitatively describe the relative importance of

\begin{tabular}{|c|c|c|}
\hline Scale & Definition & Description \\
\hline 0.5 & $\begin{array}{l}\text { Equally } \\
\text { important }\end{array}$ & $\begin{array}{l}\text { The two elements are equally } \\
\text { important according to } \\
\text { comparison. }\end{array}$ \\
\hline 0.6 & $\begin{array}{l}\text { Slightly more } \\
\text { important }\end{array}$ & $\begin{array}{l}\text { One element is slightly more } \\
\text { important than the other } \\
\text { according to comparison. }\end{array}$ \\
\hline 0.7 & $\begin{array}{l}\text { Significantly } \\
\text { more } \\
\text { important }\end{array}$ & $\begin{array}{l}\text { One element is significantly } \\
\text { more important than the other } \\
\text { according to comparison. }\end{array}$ \\
\hline 0.8 & $\begin{array}{l}\text { Much more } \\
\text { important }\end{array}$ & $\begin{array}{l}\text { One element is much more } \\
\text { important than the other through } \\
\text { comparison of the two } \\
\text { elements. }\end{array}$ \\
\hline 0.9 & $\begin{array}{l}\text { Extremely } \\
\text { important }\end{array}$ & $\begin{array}{l}\text { One is extremely more } \\
\text { important than the other } \\
\text { according to comparison. }\end{array}$ \\
\hline $\begin{array}{c}0.1,0.2,0.3 \\
0.4,0.5\end{array}$ & $\begin{array}{l}\text { Negative } \\
\text { contrast }\end{array}$ & $\begin{array}{l}\text { If the element ai is compared } \\
\text { with the element aj to judge rij, } \\
\text { the judgment obtained from the } \\
\text { comparison is } r j \mathrm{i}=1-\mathrm{r}_{\mathrm{ij}} \text {. }\end{array}$ \\
\hline
\end{tabular}
any two schemes with respect to a criterion, corresponding values can be given based on the scale of 0.1-0.9 in Table 1 below.

Table 1 0.1-0.9 number scale

(3) According to the fuzzy consistent matrix, the consistency of the matrix shall be checked first. After mathematical manipulation, the following formula is used to solve the weight value wi of elements in each layer (Formula 3).

$$
w_{i}=\frac{1}{n}-\frac{1}{2 \alpha}+\frac{1}{n \alpha} \times \sum_{k=1}^{n} r_{i k}, \quad \mathrm{i} \in \Omega
$$

Where, $\mathrm{n}$ is the order of matrix R, $\alpha=(n-1) / 2$. 
If rij is scaled according to Table 2.1 and rij $=1-\mathrm{rji}, \mathrm{R}$ is a fuzzy consistent matrix. That is, it is unnecessary to check the consistency of the matrix.

(4) If the fuzzy consistent matrix is satisfied, the weight value wi of elements in each layer can be solved.

Determination of the weight of antifouling performance evaluation factors

The evaluation system includes two levels according to the evaluation of antifouling performance of groundwater in the study area, with reference to the steps above:

Level 1 is the target layer of evaluation, namely the antifouling performance of groundwater;

Level 2 is the factor layer of evaluation, namely $\mathrm{D}, \mathrm{R}$, $\mathrm{A}, \mathrm{S}, \mathrm{L}, \mathrm{I}$ and $\mathrm{C}$ in the model above.

Hence, the evaluation factors in level 2 were pairwise compared. The importance scale of factors (membership) obtained from pairwise comparison was scored by several experts in hydrogeology. The average value of the scores was obtained after removal of the highest and lowest values. The fuzzy consistent matrix $\mathrm{R}$ of antifouling performance of groundwater in Tongliao was constructed based on AHP, as shown in Table 2.

Table 2 Fuzzy consistent matrix R of groundwater vulnerability in Horqin Region, Tongliao

\begin{tabular}{|c|c|c|c|c|c|c|c|}
\hline Index & $\mathrm{D}$ & $\mathrm{R}$ & $\mathrm{A}$ & $\mathrm{S}$ & $\mathrm{L}$ & $\mathrm{I}$ & $\mathrm{C}$ \\
\hline $\mathrm{D}$ & 0.5 & 0.6 & 0.7 & 0.7 & 0.9 & 0.5 & 0.7 \\
\hline $\mathrm{R}$ & 0.4 & 0.5 & 0.6 & 0.7 & 0.8 & 0.4 & 0.6 \\
\hline $\mathrm{A}$ & 0.3 & 0.4 & 0.5 & 0.6 & 0.8 & 0.4 & 0.5 \\
\hline
\end{tabular}

\begin{tabular}{|c|c|c|c|c|c|c|c|}
\hline S & 0.3 & 0.3 & 0.4 & 0.5 & 0.7 & 0.3 & 0.4 \\
\hline E & 0.1 & 0.2 & 0.2 & 0.3 & 0.5 & 0.2 & 0.2 \\
\hline I & 0.5 & 0.6 & 0.6 & 0.7 & 0.8 & 0.5 & 0.4 \\
\hline C & 0.3 & 0.4 & 0.5 & 0.6 & 0.8 & 0.6 & 0.5 \\
\hline
\end{tabular}

The weight of each index for the evaluation of antifouling performance of groundwater in Horqin Region, Tongliao can be obtained according to the fuzzy consistency test and calculation, as shown in Table 3.

Table 3 Weights of evaluation indexes for the evaluation of antifouling performance of groundwater in Horqin Region,

\begin{tabular}{|c|c|c|c|c|}
\hline $\begin{array}{c}\text { Evaluation } \\
\text { index }\end{array}$ & $\mathrm{D}$ & $\mathrm{R}$ & $\mathrm{A}$ & $\mathrm{S}$ \\
\hline Weight & 0.195 & 0.167 & 0.143 & 0.114 \\
\hline $\begin{array}{c}\text { Evaluation } \\
\text { index }\end{array}$ & $\mathrm{L}$ & $\mathrm{I}$ & $\mathrm{C}$ & \\
\hline Weight & 0.057 & 0.171 & 0.152 & \\
\hline
\end{tabular}

\subsection{Scores of index factors}

Different index factors should be quantified uniformly into scores from 1 to 10 in the model calculation due to their different properties and dimensions during the evaluation of antifouling performance of groundwater. Their scores reflect the influence of index factors on the vulnerability of groundwater. Generally, 1 indicates the smallest influence, and 10 the biggest influence. Table 4 shows the specific scores.

Table 4 Category and score of each index factor in DRASTIC model

\begin{tabular}{|c|c|c|c|c|c|c|c|c|c|c|c|c|c|}
\hline \multicolumn{2}{|c|}{$\mathrm{D}$} & \multicolumn{2}{|c|}{$\mathrm{R}$} & \multicolumn{2}{|c|}{$\mathrm{A}$} & \multicolumn{2}{|c|}{$\mathrm{S}$} & \multicolumn{2}{|c|}{$\mathrm{L}$} & \multicolumn{2}{|c|}{$\mathrm{I}$} & \multicolumn{2}{|c|}{$\mathrm{C}$} \\
\hline $\begin{array}{c}\text { Scope } \\
(\mathrm{m})\end{array}$ & Score & $\begin{array}{c}\text { Scope } \\
(\mathrm{m})\end{array}$ & Score & $\begin{array}{l}\text { Scope } \\
(\mathrm{m})\end{array}$ & Score & $\begin{array}{c}\text { Scope } \\
(\mathrm{m})\end{array}$ & Score & Scope & Score & Scope & Score & Scope & Score \\
\hline$>30$ & 1 & 0 & 1 & Clay & 1 & $\begin{array}{c}\text { Non- } \\
\text { swellable } \\
\text { and non- } \\
\text { condensi } \\
\text { ng clay }\end{array}$ & 1 & Wasteland & 2 & $\begin{array}{l}\text { Mainly } \\
\text { clay }\end{array}$ & 1 & 0 & 1 \\
\hline $\begin{array}{l}30- \\
22.5\end{array}$ & 2 & 51 & 2 & $\begin{array}{l}\text { Silty } \\
\text { clay }\end{array}$ & 2 & Rubbish & 2 & $\begin{array}{l}\text { Lake and } \\
\text { reservoir }\end{array}$ & 3 & Silty clay & 2 & 4.1 & 2 \\
\hline $\begin{array}{c}22.5- \\
15 \\
\end{array}$ & 3 & 71.4 & 3 & Silt & 3 & $\begin{array}{c}\text { Clayey } \\
\text { subclay }\end{array}$ & 3 & $\begin{array}{c}\text { Residentia } \\
1 \text { site }\end{array}$ & 6,7 & Silt & 3 & 12.2 & 3 \\
\hline $15-9$ & 5 & 91.8 & 4 & Silt & 4 & $\begin{array}{l}\text { Silty } \\
\text { gravel } \\
\text { subclay }\end{array}$ & 4 & $\begin{array}{c}\text { Farmland } \\
\text { (excluding } \\
\text { (paddy } \\
\text { field) } \\
\end{array}$ & 7 & Silt & 4 & 20.3 & 4 \\
\hline $9-4.5$ & 7 & 117.2 & 5 & $\begin{array}{l}\text { Silty } \\
\text { fine } \\
\text { sand }\end{array}$ & 5 & Subclay & 5 & $\begin{array}{c}\text { Farmland } \\
\text { (excluding } \\
\text { (paddy } \\
\text { field) }\end{array}$ & 8 & $\begin{array}{l}\text { Silty fine } \\
\text { sand }\end{array}$ & 5 & 28.5 & 5 \\
\hline$\frac{4.5-}{1.5}$ & 9 & 147.6 & 6 & $\begin{array}{l}\text { Fine } \\
\text { sand }\end{array}$ & 6 & $\begin{array}{c}\text { Gravelly } \\
\text { subclay }\end{array}$ & 6 & $\begin{array}{l}\text { Land for } \\
\text { mining } \\
\text { and } \\
\text { industry }\end{array}$ & 9 & Fine sand & 6 & 34.6 & 6 \\
\hline $1.5-0$ & 10 & 178 & 7 & $\begin{array}{l}\text { Mediu } \\
\text { m sand }\end{array}$ & 7 & $\begin{array}{c}\text { Swellabl } \\
\text { e or } \\
\text { condensi } \\
\text { ng clay }\end{array}$ & 7 & $\begin{array}{l}\text { Paddy } \\
\text { field }\end{array}$ & 10 & $\begin{array}{l}\text { Medium } \\
\text { sand }\end{array}$ & 7 & 40.7 & 7 \\
\hline & & 216 & 8 & $\begin{array}{c}\text { Coarse } \\
\text { sand }\end{array}$ & 8 & Peat & 8 & & & $\begin{array}{c}\text { Coarse } \\
\text { sand }\end{array}$ & 8 & 61.1 & 8 \\
\hline & & 235 & 9 & $\begin{array}{c}\text { Sand } \\
\text { gravel }\end{array}$ & 9 & Sand & 9 & & & $\begin{array}{c}\text { Sand } \\
\text { gravel }\end{array}$ & 9 & 71.55 & 9 \\
\hline & & 254 & 10 & $\begin{array}{l}\text { Gravel } \\
\text { cobble }\end{array}$ & 10 & Gravel & 10 & & & $\begin{array}{l}\text { Gravel } \\
\text { cobble }\end{array}$ & 10 & 81.5 & 10 \\
\hline
\end{tabular}

Note: In addition to the $\mathrm{pH}$, the units of the concentration of the rest chemical mass parameters are $\mathrm{mg} / \mathrm{L}$.

\section{SUMMARY}

MAPGIS software was used to process all evaluation factors in the groundwater vulnerability assessment. The attribute library management function and spatial data analysis function were mainly used as analysis tools for the evaluation of groundwater vulnerability in Horqin Region, Tongliao, which simplified the analysis process and improved the calculation accuracy . 
Attribute fields were added to the grading chart of evaluation factors. On this basis, the region-to-region combined analysis function in the MAPGIS spatial analysis module was used for regional spatial superposition operation of evaluation factors. Then, the result was substituted into the new evaluation model for evaluation.

Evaluation results

Due to the change of factors in the groundwater

Table 5 Correspondence of level, vulnerability and antifouling performance conclusions

\begin{tabular}{|c|c|c|c|c|c|c|c|c|c|c|}
\hline Level & 1 & 2 & 3 & 4 & 5 & 6 & 7 & 8 & 9 & 10 \\
\hline $\begin{array}{c}\text { Vulnerability } \\
\text { description }\end{array}$ & $\begin{array}{c}\text { Extremely } \\
\text { low }\end{array}$ & $\begin{array}{c}\text { Very } \\
\text { low }\end{array}$ & $\begin{array}{c}\text { Relatively } \\
\text { low }\end{array}$ & $\begin{array}{c}\text { A little } \\
\text { low }\end{array}$ & $\begin{array}{c}\text { Slightly } \\
\text { low }\end{array}$ & $\begin{array}{c}\text { Slightly } \\
\text { high }\end{array}$ & $\begin{array}{c}\text { A little } \\
\text { high }\end{array}$ & $\begin{array}{c}\text { Relatively } \\
\text { high }\end{array}$ & $\begin{array}{c}\text { Very } \\
\text { high }\end{array}$ & $\begin{array}{c}\text { Extremely } \\
\text { high }\end{array}$ \\
\hline $\begin{array}{c}\text { Antifouling } \\
\text { performance } \\
\text { description }\end{array}$ & $\begin{array}{c}\text { Extremely } \\
\text { high }\end{array}$ & $\begin{array}{c}\text { Very } \\
\text { high }\end{array}$ & $\begin{array}{c}\text { Relatively } \\
\text { high }\end{array}$ & $\begin{array}{c}\text { A little } \\
\text { high }\end{array}$ & $\begin{array}{c}\text { Slightly } \\
\text { high }\end{array}$ & $\begin{array}{c}\text { Slightly } \\
\text { low }\end{array}$ & $\begin{array}{c}\text { A little } \\
\text { low }\end{array}$ & $\begin{array}{c}\text { Relatively } \\
\text { low }\end{array}$ & $\begin{array}{c}\text { Very } \\
\text { low }\end{array}$ & $\begin{array}{c}\text { Extremely } \\
\text { high }\end{array}$ \\
\hline $\begin{array}{c}\text { Degree of } \\
\text { pollution }\end{array}$ & $\begin{array}{c}\text { Extremely } \\
\text { difficult to } \\
\text { pollute }\end{array}$ & $\begin{array}{c}\text { Very } \\
\text { difficult } \\
\text { to } \\
\text { pollute }\end{array}$ & $\begin{array}{c}\text { Relatively } \\
\text { difficult to } \\
\text { pollute }\end{array}$ & $\begin{array}{c}\text { A little } \\
\text { difficult } \\
\text { to } \\
\text { pollute }\end{array}$ & $\begin{array}{c}\text { Slightly } \\
\text { difficult } \\
\text { to } \\
\text { pollute }\end{array}$ & $\begin{array}{c}\text { Relatively } \\
\text { easy to } \\
\text { pollute }\end{array}$ & $\begin{array}{c}\text { A little } \\
\text { easy to } \\
\text { pollute }\end{array}$ & $\begin{array}{c}\text { Relatively } \\
\text { easy to } \\
\text { pollute }\end{array}$ & $\begin{array}{c}\text { Very } \\
\text { easy to } \\
\text { pollute }\end{array}$ & $\begin{array}{c}\text { Extremely } \\
\text { easy to } \\
\text { pollute }\end{array}$ \\
\hline
\end{tabular}

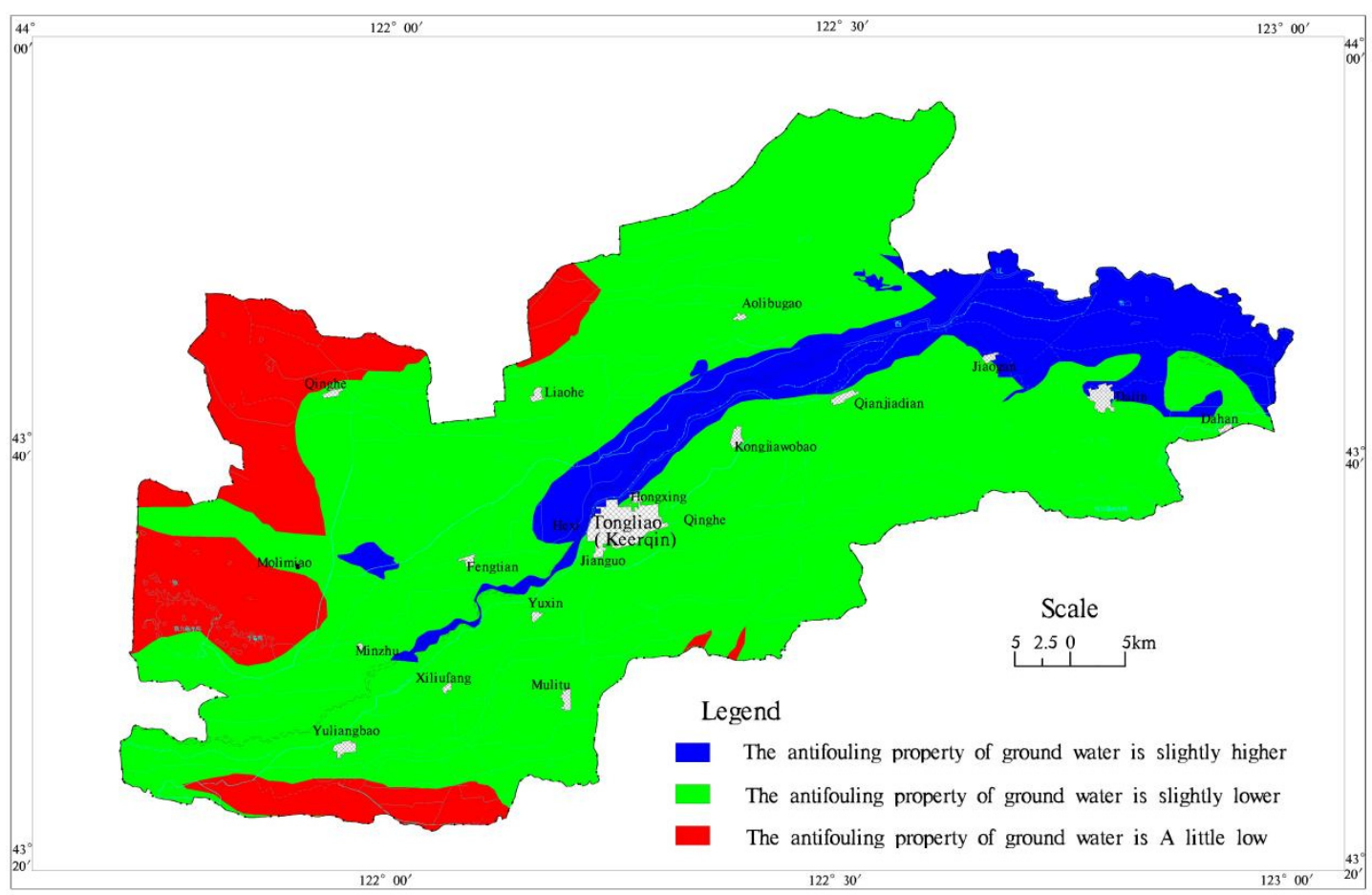

Figure 1 Map of groundwater vulnerability assessment results

As shown in Figure 1, the study area can be divided into 3 levels according to the vulnerability assessment results of groundwater in the study area and the correspondence shown in Table 5: areas with slightly low vulnerability (slightly difficult to pollute; the evaluation result is 4-5), areas with slightly high vulnerability (slightly easy to pollute; the evaluation result is 5-6) and areas with a little high vulnerability (a little easy to pollute; the evaluation result is 6-7).

Areas with a little low antifouling performance of vulnerability evaluation, the DRASTIC model was modified to build a new evaluation model (Formula 4):

$\mathrm{DI}=\mathrm{DrDw}+\mathrm{RrRw}+\mathrm{ArAw}+\mathrm{SrSw}+\mathrm{LrLw}+\mathrm{IrIw}+\mathrm{CrCw}=$ DRASLIC …… Formula 4

The evaluation results were obtained according to the new model. A result chart of groundwater vulnerability evaluation was drawn as below according to the levels in Table 5. 
groundwater table of the areas is the minimum. In terms of the lithology, the vadose zone is featured with medium sand, medium fine sand or fine sand and small thickness. The surface soil is mainly sandy with poor natural protection capability. The land is mainly dry farmland. Surface water and some pollutants have strong vertical permeability. The phreatic aquifer has high permeability and rich water. Contaminants are easily diffused and groundwater is relatively easy to be contaminated in the working area.

Areas with slightly high groundwater antifouling performance (i.e. slightly low groundwater vulnerability) are mainly distributed in the main stream valley plain area of West Liaohe River in Horqin Region, Dahan TownDalin Town-Jiaogan Town and the east area of Molimiao Town. The buried depth of groundwater in these areas is basically greater than $7 \mathrm{~m}$. Such areas account for $16.53 \%$ of the study area. The depth to groundwater table of the areas is the maximum. In terms of the lithology, the surface soil is featured with silty silt, and the vadose zone is featured by shaly sand or silty fine sand, with large thickness. The phreatic aquifer has the minimum permeability and good natural protection capacity. The land is mainly rivers, wastelands and some underdeveloped urban land. The surface water and some pollutants have weak vertical permeability, and it is not easy for contaminants to diffuse. The groundwater is relatively difficult to be contaminated in the working area.

Areas with slightly low groundwater antifouling performance (i.e. slightly high groundwater vulnerability) are other areas except the above two types of areas, which are widely distributed in Horqin Region, Tongliao. Such areas account for $65.22 \%$ of the study area. The depth to groundwater table of the areas is large, $5-7 \mathrm{~m}$. In terms of the lithology, the vadose zone is featured with fine sand or shaly medium and fine sand. There has been a small quantity of shaly particles in the vadose zone, and the rainfall infiltration coefficient also begins to decrease. The surface soil is mainly shaly silt, and some areas are of sandy lithology. The possibility for groundwater contamination in the working area is between that of the two areas above.

\section{CONCLUSION}

The impact of terrain was removed and land use status was added to modify the DRASTIC model into a new model DRASLIC based on Chinese and overseas literature and actual conditions in the study area. AHP was applied to figure out new weights. The evaluation result is that the groundwater vulnerability in the study area can be divided into three grades. The subdivision of groundwater antifouling performance obtained is consistent with the regional environmental hydrogeological conditions.

The results obtained by the combination of the antifouling performance index system with GIS technology provide a basis for the decision-making on groundwater management and protection in Horqin Region, Tongliao and can also be extensively applied to the planning and design of a groundwater monitoring network, the site selection of waste landfills, the evaluation and control of groundwater pollution, the selection and protection of water sources, etc.

\section{References}

1. Zhang Xuegang and Mao Yuanyuan, et al. (2009) Assessment of Groundwater Vulnerability and Pollution Risk in Zhangji . Hydrogeology \& Engineering Geology, 1: 51 55.

2. Zhao Shubai. (1988) Practical Decision-making Method - Analytic Hierarchy Process. Tianjin: Tianjin University Press.

3. Li Yong and Feng Yong. (2003) Determination of Objective Weight in Multi-Objective Decision . Journal of Gansu University of Technology, 29(3):118-119.

4. Song Guangxing and Zou Ping. (2001)Method of Determining the Weight of the Decision-maker in Multi-Attribute Group Decision-making . Systems Engineering, 19(4):84-89.

5. Zhang Haitao, Liu Chaoying and Tian Shui. (2004)Subjective and Objective Combination Method of Weight Determination . Journal of Jianghan University (Natural Science), 32(4):63-65.

6. Zhu Yin, Meng Zhiyong and Shan Shuyu. (1999)Weight Calculation by AHP . Journal of Beijing Jiaotong University, 23(5):119-122.

7. Wang Jing and Zhang Jinsuo. (2001)Comparison of Several Methods for Determining Weight Vector in Comprehensive Evaluation. Journal of Hebei University of Technology, 30(2): 52-57.

8. Wang Wei and Zhang Yuzhi. (2006,)Study on Weight Vector Solving Method of Fuzzy AHP . Control and Decision, 21(2):184-188.

9. Zhu Jianjun. (2005)Research on Some Problems of Analytic Hierarchy Process and Its Application. Doctoral thesis of Northeastern University.

10. Li Song, Qiu Wei, Zhao Qingliang and Liu Zhengmao. (2006)Application of Analytical Hierarchy Process to Assessment of Eco-Environment Quality in Heilongjiang Province. Environmental Science, 27(5):1031-1034.

11. Zhu Xiaohua and Yang Xiuchun. (2001)Study on Application of Analytic Hierarchy Process in Regional Ecological Quality Assessment . Scientific and Technological Management of Land and Resources, (5): 45-45.

12. Hu Anyan, Guo Sheng Lian, Liu Yan and Lin Kairong. (2006)Fuzzy Comprehensive Evaluation of Ecological Environment Quality in Inland River Basin in Arid Areas . Journal of Geological Hazards and Environment Preservation, 17(2): 69-73.

13. Yang Shu, Chu Yu, Yang Xiangkui and Lou Benjun. (2005)Application of Analytic Hierarchy Process (AHP) in the Evaluation of Geo-Environmental Quality in the Sanjiang Plain . Geological Bulletin of China, 24(5):485-490.

14. Cui Jian, Li Xiao and Du Jizhong, et al. (2011)GISbased Assessment of Antifouling Performance of Shallow Groundwater in Alluvial Fan of Hunhe River. Geology and Resources, 20(2): 137-140. 